УДК 339.7

DOI: https://doi.org/10.32782/2413-9971/2019-28-57

\author{
Shagina Sofia \\ Student Master's Degree \\ Odessa I. I.Mechnikov National University \\ Bychkova Natalia \\ PhD, Associate Professor of the Department \\ of World Economy and International Economic Relations \\ Odessa I. I.Mechnikov National University
}

\begin{abstract}
Шагіна C. O.
студентка магістратури

спеиіальності «Міжнародні економічні відносини»

Одеського начіонального університету імені I. I. Мечникова

Бичкова Н. В.

кандидат економічних наук,

дочент кафедри світового господарства

та міжнародних економічних відносин

Одеського національного університету імені I. І. Мечникова
\end{abstract}

\title{
THE ROLE OF VALUE DRIVERS IN VALUE-BASED MANAGEMENT CONCEPT
}

Summary. The article deals with the concept of value-based management of corporations in modern conditions. Basic modern conceptual ideas of famous world economists are revealed. The concept and basic theories of value drivers are analyzed by the authors. Various approaches and classifications to the theory of value-based management and value drivers are examined. Process of analyzing value drivers that is used by corporate management is explained. The article gives examples of implementation of value-based indicators in the most successful corporations of the world at the present stage. The authors are analyzing the impact of value drivers on corporate value per employee, as exemplified by the corporations of Forbes 2000 using an econometric model. The concepts of such value-based indicators as EBITDA and EV/EBITDA are revealed.

Key words: value-based management, corporate finance, value, value driver, corporate governance.

Formulation of the problem. At the present stage, firms are operating in a business environment that requires them to implement a system of metrics that illustrates value and profitability better. It should be noted that the current accounting systems do not fully meet the conditions of functioning of the effective capital markets and do not meet the requirements of the main stakeholders. The constant improvement of efficiency in the capital markets requires more efficient distribution of capital within firms. Thus, a new scorecard and valuebased management (VBM, Value-based management) have emerged, i.e. managing a company based on a value approach to maximize the market value of the company.

Value-based management is based on the concept of value. The cost of a company depends on many factors called value drivers. At the present stage, the companies use cost driver analysis to increase the efficiency of their business and increase its value, and the cost driver analysis helps strategic planning for company management.

Analysis of recent research and publications. The analysis of value drivers and value based management concept is devoted to the works of the folowing researchers: V. Fruhan, A. Rappaport, T. Copeland, T. Coller, R. Morin and others.

Setting objectives. The purpose of this research is to define the notion of value drivers and their role in value-based corporate finance management.

The main material research. At the present stage, the existing accounting systems do not fully satisfy the conditions of functioning of effective markets. A new set of metrics, 
such as the value-based management (VBM), is a topical and necessary one, that is the value-based management that maximizes the market value of a company and reflects the opportunities and threats of its operations [1].

The first conceptual ideas of the value-based financial management were driven by changes in the economic environment and began to emerge in the United States in the 1980s. The authors of the theory are V. Fruhan (1979) and A. Rappaport (1986) .

The concept of VBM was created in the context of social and economic changes in the late twentieth century. The factors that contributed to its development include: the increased volume of using the private capital, the revolution in information technology and the globalization of markets. The widespread use of this management concept has completely changed the way companies operate worldwide [2]

Corporate governance has a constant purpose in maximizing shareholder income. But while maximizing shareholder value is an important corporate objective, it is not sufficiently specific and accountable for operational management, which also needs to know which factors can mostly affect value and which factors can be most easily influenced.

An important part of VBM is a thorough understanding of the performance variables that will actually generate business value, i.e. key drivers of value. This understanding is important because the organization cannot directly influence cost. It should focus on what it can affect: customer satisfaction, capital costs, and more [3].

Value driver is any variable that affects the value of the company. The variables that determine the value of the company can be expressed in different quantities. These are the variables which the performance of the enterprise depends on. In other words, company value drivers are critical factors that affect the value components and their formation, they are directly determined and dependent on the management decisions that help to analyze and control the enterprise value creation process.

There are many factors that create value, including: proprietary technologies, market position, brand, various product lines, patented products and more. Elements common to all value-adding industries include:

- Stable, motivated management team

- Operating systems that improve cash flow sustainability

- A solid, diversified customer base

- The appearance of the object matches the asking price

- A realistic growth strategy

- Effective financial control

- Good and improving cash flow [4].

Value driver analysis is an important basis for strategic planning, helping management to streamline its operations to identify critical strategic levels. In order to study changes in shareholder value creation, it is necessary to identify those variables that can be controlled, modified, managed or even manipulated by the company management.

Identifying value drivers is a three-step process:

1. Development of a «map» of value drivers for the enterprise

2. Cost driver sensitivity test

3. Controllability test [5].

In the first stage, manager documents what specific factors affect such broad metrics as operating profit, etc. In the second stage, after the baseline has been built for each operating factor, the manager should analyze how changes in each factor affect the overall cost of the business. The next step is to examine each variable to see if it can be controlled [6].

Once management has established consensus around major cost drivers, they can focus on the logistics of improving driver performance.
Copeland, Koller, and Moorin classify cost drivers in three levels:

1. Drivers of general value are established in terms of Return on Equity (ROE), which includes operating margin and invested capital.

2. The next level of value drivers is the business unit level drivers (variables such as customer mix, sales performance, or cost sharing).

3. The last tier is operational, where variables such as percentage of capacity utilized (plant or machine), delivery costs, and terms and conditions of debtors or creditors are directly controlled and modified by the decisions of the executives

By creating as many value drivers as possible, the company can increase its influence in the market. In order to constantly increase the value of products and services, businesses must constantly monitor the market so that they can be the first to take advantage of demand and behavior of the buyers [7].

The critical success factors should be identified during strategic management of the company and then the key performance indicators should be identified. Value creation is driven by a reasonable balance of growth, return on capital, cost of capital, and ability to be effective over time.

According to the concept of Rappaport (1986), management measures can be evaluated on the basis of significant factors and appropriate management decisions. Alfred Rapport has offered seven drivers in the business that can be managed to create value:

- sales growth;

- increase in operating profit margin;

- reduction of the cash tax rate;

- reduction of the working capital investment (WCI);

- reduction of the investments in fixed capital;

- reduction of the weighted average cost of capital (WACC);

- increase in the period of competitive advantage [8].

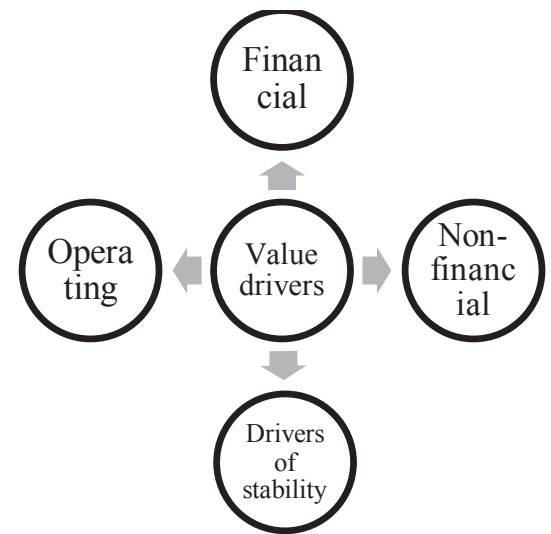

Fig. 1 Groups of value drivers

Source: created on the basis [7]

The financial group usually includes those financial components that optimize the cost of capital, its distribution and structure, participate in the formation of profits, etc.

It is important to note that the financial drivers are often of an evaluative nature: they are not separate items of the balance sheet and profit and loss statement, but are indicators of growth, change or relationship of these items.

For operating drivers, all those factors that affect the amount of cash flow are generated by increasing efficiency or growth. Unable to influence financial ratios directly, the company executes cost-oriented management by influencing operating leverage.

The drivers of sustainability include those components of business processes that contribute to the normal functioning 
of the enterprise in the long run. These factors reflect the relationship between external processes occurring in the market for a company and internal ones that affect value. These drivers include:

- Changes in legislation.

- Market changes.

- Reputational risks of the company.

Non-financial drivers include factors that indirectly affect cash flow generation, and come from the features of doing business. In this group of drivers the following are highlighted:

- Agency conflict;

- Customer relationships;

- Relations with business owners;

- Relations with partners.

Thus, the model of the value drivers divides the activity of the company into separate business processes, phenomena and indicators related to value creation [8].

The impact of value drivers on enterprise value per employee is analyzed on the example of the five most successful Forbes 2000 corporations in the world: Apple, Royal Dutch Shell, Berkshire Hathway, Exxon Mobil, Toyota Motors. The list is based on several criteria: income, profit, value of assets of the company and its market value. Because of the using any one parameter will result in an unbiased and incomplete estimate, Forbes uses a coefficient that equally takes into account four parameters [9].

Enterprise value (hereinafter EV) is one of the most important indicators that an investor should focus on. The indicator is calculated by adding to the market capitalization of the net debt of the company, which is calculated by adding up the short- and long-term debt of the company, the share of minority shareholders and the capital of the preferred shareholders minus cash and cash equivalents from this amount.

Company Value is a theoretical index for investors of a company price when it is absorbed. EV is an estimate. Investors use valuation ratios to compare companies. The smaller the valuation factor, the more return the investor will receive on the invested capital.

To evaluate the impact of value drivers, econometric model is constructed via GRETL program software.
The dependent variable is the company value divided by the number of company employees (EVqofworkers). Independent variables were selected: earnings before interest, taxes and depreciation (EBITDA), weighed average cost of capital (WACC), return on assets (ROA), earnings yield (earningsyield). The statistics are taken over a 5 year period.

Thus, a 3 -factor econometric model of the following form was built:

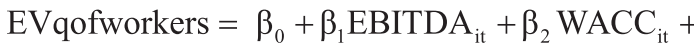

$$
\begin{aligned}
& +\beta_{3} \text { ROA }_{i t}+\beta_{4} \text { earningsyield }_{\mathrm{it}}
\end{aligned}
$$

The data includes 25 observations; the period of analysis consists from annual data from 2014 to 2018. Descriptive statistics of the model variables is available in the Table 1 .

On the basis of the use of Ordinary least square (1OLS) with special modification for panel data and software gretl 1.9.6 the following estimates of regression coefficients were obtained (Tab. 2).

The model was tested for multicollinearity. According to VIF-index, the multicollinearity in a model is absent (VIF $<10)$.

According to the Table 2, the model with all significant coefficients is obtained.

Fisher's index is 19,3: this indicator is less than the one in the table, so the regression equation estimate is statistically reliable and the coefficient of determination is statistically significant.

The determination coefficient is $73 \%$, which indicates the high accuracy of the model approximation (the model describes the phenomenon chosen well). Regarding significance, the least significant factor is the weighted average cost (p-value is the highest: 0,0334). The smallest p-value was found for the EBITDA ratio, therefore it is the most significant in the model.

The significant variable has an inverse relationship with the yield of the securities as well as a direct relationship with the other two indicators. If the yield on securities changes by one standard deviation, the value of the company per employee will be reduced by 0.3 standard deviations.

When profits before interest, taxes and depreciation (EBITDA) are deducted by one standard deviation, the value

Descriptive statistics

\begin{tabular}{|c|c|c|c|c|c|}
\hline Variable & Min & Max & Mean & Median & St. Dev \\
\hline EBITDA & 17,633 & 87 & 48,48 & 41,321 & 18,056 \\
\hline WACC & 2,92 & 9,99 & 6,595 & 6,87 & 2,06 \\
\hline earningsyield & 1,63 & 12,5 & 7,56 & 7,7 & 3,18 \\
\hline
\end{tabular}

Source: calculated by the authors

Table 2

Coefficients and statistical estimates

\begin{tabular}{|c|c|c|c|c|}
\hline & Pooled & Fixed Effects & Random effects & VIF \\
\hline const & $\begin{array}{l}-1.366 \\
(-1.335) \\
\end{array}$ & $\begin{array}{c}-0,99 \\
(-1,118) \\
\end{array}$ & $\begin{array}{c}-1.107 \\
(-1.148) \\
\end{array}$ & - \\
\hline EBITDA & $\begin{array}{c}0.093 \\
(3,316) \\
* * *\end{array}$ & $\begin{array}{c}0,103 \\
(5,625) \\
* * *\end{array}$ & $\begin{array}{c}0.103 \\
(5.766) \\
* * *\end{array}$ & 3,676 \\
\hline WACC & $\begin{array}{c}0.433 \\
(2,276) \\
* *\end{array}$ & $\begin{array}{c}0,279 \\
(2,005) \\
*\end{array}$ & $\begin{array}{c}0.301 \\
(2.262) \\
* *\end{array}$ & 2,2 \\
\hline earningsyield & $\begin{array}{c}-0.368 \\
(-3,057) \\
* * *\end{array}$ & $\begin{array}{c}-0.351 \\
(-5.928) \\
* * *\end{array}$ & $\begin{array}{c}-0.352 \\
(-6.043) \\
* * *\end{array}$ & 2,1 \\
\hline $\mathrm{R}^{2}$ & 0,73 & - & - & - \\
\hline $\mathrm{F}$ & 19,3 & - & - & - \\
\hline
\end{tabular}

Source: calculated by the authors 
of the company produced by one employee will increase by 0.09 standard deviations.

Thus, we can conclude that in the most successful companies in the world the key value driver is EBITDA.

With the help of EBITDA it is possible to compare the financial results of competing companies operating in one industry, to determine the level of solvency of the company and the probability of repayment of existing debt.

This indicator assesses the attractiveness of the company for its absorption or lending well. EBITDA is a convenient tool for analyzing property redistribution, as it allows determining the effectiveness of a change of owner to a new one, capable to provide a lower rate of the company's loan. Another advantage of EBITDA is the ability to calculate this index quite simply and quickly.

EBITDA reflects the amount of profit before deducting all required payments from the company. Thus, it does not disclose the profitability of the company itself and its profit. It is rather the profitability of the main activity of the company (business) and the ability of the company in this direction to work and earn.

The main drawback of the EBITDA is that it does not reflect the funds spent on the purchase of assets: real estate, equipment, vehicles and anything else that will work for several years. But almost all assets age, wear out, lose in price. And over time, the old equipment must be replaced with the new one. Money for it should be put aside today. Otherwise, at the end of a certain period it will be possible to close the enterprise.
The table shows the financial performance of corporations as of 2018. Based on the data, we can conclude that the best results in adding company value are shown by Apple.

However, the EV / EBITDA multiplier shows that it will take 11 years for the operating profit to cover its invested capital, the largest indicator among the selected companies.

It should be noted that the multiplier is used to compare companies in the same industries, so the statement that investing in Apple may be unprofitable for an investor is incorrect.

The multiplier is good because it gives a net result, without adjustment for the country of incorporation (taxes), debt load (interest), capital intensity (depreciation), company size and accounting currency (as this is a relative indicator). Due to EV / EBITDA, the potential investor can compare investments in companies from different countries and in different sizes and get comparable results.

Conclusions. Thus, it can be concluded that value is an important indicator of evaluating the performance of a company, since it takes into account the long-term interests of all stakeholders in the company, not just its shareholders. Valuebased management is an integration process aimed at improving the process of strategic and operational decision-making in the organization as a whole, with an emphasis on the key factors that are relevant to each company.

The important steps in development of a company's financial growth strategy are identifying an integral key indicator that signals the creation or destruction of value, and identifying value drivers at different levels of management.

Financial indicators of corporations for 2018

Table 3

\begin{tabular}{|l|c|c|c|}
\hline & EV, USD mIn & EBITDA, USD mln & EV/EBITDA \\
\hline Apple & 973 & 82,872 & 11,74 \\
\hline Royal Dutch Shell & 334 & 63,379 & 5,26 \\
\hline Berkshire Hathway & 514 & 46,632 & 7,022 \\
\hline Exxon Mobil & 366 & 47,591 & 8,69 \\
\hline Toyota Motors & 321 & 36,905 & 8,7 \\
\hline
\end{tabular}

Source: created on the basis [10]

\section{References:}

1. Shagina S.O., Bichkova N.V. Koncepcija vartisno-orientovanogo upravlinnja jak osnova upravlinnja finansami korporacij na suchasnomu etapi [The concept of value-based management as the basis of corporate finance management at the present stage] / Dev'jata Mizhnarodna naukovo-praktichna konferencija "Dobrobut nacij v umovah global'noï nestabil'nosti" : [zb. nauk. pr.] . ONU im. I.I. Mechnikova, Programa im. ZHana Mone ; za zag. red. S.O. JAkubovs'kogo. - Odesa : Odes'kij nac. un-t, 2019. - pp. 41-42.

2. Shagina S.O. Osoblivosti vikoristannja vartisno-orientovanih pokaznikiv dlja ocinki dijal'nosti korporacij na suchasnomu etapi [Features of using value-based metrics to evaluate the performance of corporations at the current stage] . Social'no-politichni studiï. - 2019. - № 3. - pp. 176-177.

3. Shagina S.O. Konceptual'ni pidhodi do vartisno-orientovanogo upravlinnja finansami korporacij na suchasnomu etapi [Conceptual approaches to value-based corporate finance management at the current stage]. Regional'na ekonomika ta upravlinnja. 2019. - №3. - pp. 101-105.

4. Value drivers white paper [Electronic resource] . - Available from: http://www.peterracen.com/files/86830/Racen13.pdf (accessed 15 November 2019)

5. Identifying and Managing Key Value Drivers[Electronic resource] . - Available from: https://www.lek.com/sites/default/files/insights/ pdf-attachments/1936_Identifying_and_Managing_Key_Value_Drivers_LEK_Executive_Insights.pdf(accessed 15 November 2019).

6. What is value-based management? An excerpt from Valuation: Measuring and Managing the Value of Companies, Second Edition[Electronic resource] . - Available from: https://immagic.com/eLibrary/ARCHIVES/GENERAL/MCKNSYUS/M94000K. pdf (accessed 15 November 2019).

7. Financial and non-financial value drivers in shareholder value creation process [Electronic resource] . - Available from: https://www.researchgate.net/publication/256060882_Financial_and_Non-Financial_Value_Drivers_in_Shareholder_Value_Creation_Process (accessed 15 November 2019).

8. Opredelenie drajverov sozdanija stoimosti v sub'ektah malogo i srednego predprinimatel'stva, zanjatyh v sfere optovoj torgovli nefteproduktami [Electronic resource] . - Available from: https://naukovedenie.ru/PDF/06EVN217.pdf (accessed 15 November 2019).

9. Global 2000 - The World's Largest Public Companies 2019 - Forbes. - [Electronic resource]. - Available from: https://www.forbes.com/global2000/\#281310de335d (accessed 15 November 2019).

10. Value Investing | Market insights and news of the investment gurus. [Electronic resource] - Available from: https://www.gurufocus.com/ (accessed 15 November 2019). 


\section{Список використаних джерел:}

1. Шагіна С.О., Бичкова Н.В. Концепція вартісно-орієнтованого управління як основа управління фінансами корпорацій на сучасному етапі. Дев'ята Міжнародна науково-практична конференція "Добробут націй в умовах глобальної нестабільності" : [зб. наук. пр.] / ОНУ ім. І.І. Мечникова, Програма ім. Жана Моне ; за заг. ред. С. О. Якубовського. - Одеса : Одеський нац. ун-т, 2019. - С. 41-42.

2. Шагіна С.О. Особливості використання вартісно-орієнтованих показників для оцінки діяльності корпорацій на сучасному етапі. Соціально-політичні студії. - 2019. - № 3. - С. 176-177.

3. Шагіна С.О. Концептуальні підходи до вартісно-орієнтованого управління фінансами корпорацій на сучасному етапі. Регіональна економіка та управління. - 2019. - №3. - С. 101-105.

4. Value drivers white paper [Electronic resource] . - Available from: http://www.peterracen.com/files/86830/Racen13.pdf (дата звернення 15.11.2019).

5. Identifying and Managing Key Value Drivers[Electronic resource]. - Available from: https://www.lek.com/sites/default/files/ insights/pdf-attachments/1936_Identifying_and_Managing_Key_Value_Drivers_LEK_Executive_Insights.pdf (дата звернення 15.11.2019)

6. What is value-based management? An excerpt from Valuation: Measuring and Managing the Value of Companies, Second Edition[Electronic resource]. - Available from: https://immagic.com/eLibrary/ARCHIVES/GENERAL/MCKNSYUS/M94000K. pdf (дата звернення 15.11.2019).

7. Financial and non-financial value drivers in shareholder value creation process [Electronic resource]. - Available from: https://www.researchgate.net/publication/256060882_Financial_and_Non-Financial_Value_Drivers_in_Shareholder_Value Creation_Process (дата звернення 15.11.2019).

8. Определение драйверов создания стоимости в субъектах малого и среднего предпринимательства, занятых в сфере оптовой торговли нефтепродуктами [Электронный ресурс]. - Режим доступа: https://naukovedenie.ru/PDF/06EVN217.pdf (дата звернення 15.11.2019).

9. Global 2000 - The World's Largest Public Companies 2019 - Forbes. - [Electronic resource]. - Available from: https://www.forbes.com/global2000/\#281310de335d (дата звернення 15.11.2019).

10. Value Investing | Market insights and news of the investment gurus. [Electronic resource]. - Available from: https://www.gurufocus.com/ (дата звернення 15.11.2019).

\section{РОЛЬ ДРАЙВЕРІВ ВАРТОСТІ У КОНЦЕПЦІЇ ВАРТІСНО-ОРІЄНТВАНОГО УПРАВЛІННЯ}

Анотація. На сучасному етапі фірми працюють у бізнес-середовищі, що вимагає від них впровадити систему показників, яка краще ілюструє цінність та прибутковість. Слід зазначити, що діючі системи бухгалтерського обліку не повністю відповідають умовам функціонування ефективних ринків капіталу та не відповідають вимогам основних зацікавлених сторін. Постійне підвищення ефективності на ринках капіталу вимагає більш ефективного розподілу капіталу в межах фірм. Таким чином, з'явилася нова система показників та управління на основі вартості (VBM, управління на основі цінності) - управління компанією на основі вартісного підходу для максимізації ринкової вартості компанії. Управління на основі цінності базується на концепції вартості. Важливою частиною VBM є глибоке розуміння змінних продуктивності, які будуть фактично створювати вартість бізнесу - ключові драйвери вартості. Таке розуміння $\epsilon$ важливим, тому що організація не може впливати безпосередньо на вартість. Вартість компанії залежить від багатьох факторів, які називаються драйверами цінності. На сучасному етапі компанії використовують аналіз драйверів вартості для підвищення ефективності свого бізнесу та підвищення його вартості, а аналіз драйверів вартості допомагає стратегічному плануванню управління компанією. У статті розглядається концепція управління на основі цінностей корпорацій у сучасних умовах. Розкрито основні сучасні концептуальні ідеї відомих світових економістів. Авторами проаналізовано концепцію та основні теорії драйверів цінності. Розглядаються різні підходи та класифікації до теорії управління на основі цінності та драйверів вартості. Автори аналізують вплив драйверів вартості на корпоративну вартість на одного працівника, як показано на прикладі корпорацій Forbes 2000, використовуючи економетричну модель. Зроблено висновки щодо результатів побудованої моделі та впливу драйверів вартості на показники обраних корпорацій. Розкрито поняття таких показників на основі цінності, як EBITDA та EV / EBITDA. У статті наведено приклади впровадження ціннісних показників у найбільш успішних корпораціях світу на сучасному етапі.

Ключові слова: вартісно-орієнтоване управління , корпоративні фінанси, вартість, драйвери вартості, корпоративне управління.

\section{РОЛЬ ДРАЙВЕРОВ СТОИМОСТИ В КОНЦЕПЦИИ СТОИМОСТНО-ОРИЕНТИРОВАННОГО УПРАВЛЕНИЯ}

Аннотация. В статье рассматривается понятие стоимостного управления корпорациями в современных условиях. Раскрыты основные современные концептуальные идеи известных мировых экономистов. Понятие и основные теории факторов стоимости анализируются авторами. Рассматриваются различные подходы и классификации к теории управления стоимостью и факторов стоимости. Объясняется процесс анализа стоимостных драйверов, который используется корпоративным управлением. В статье приведены примеры реализации стоимостных показателей в наиболее успешных корпорациях мира на современном этапе. Авторы анализируют влияние факторов стоимости на корпоративную стоимость на одного сотрудника, что подтверждается примерами корпораций Forbes 2000 с использованием эконометрической модели. Раскрыты понятия таких стоимостных показателей, как EBITDA и EV / EBITDA.

Ключевые слова: управление на основе стоимости, стоимость, корпоративные финансы, стоимость, драйверы стоимости, корпоративное управление. 